This, however, is only the superficial part of the problem. A more serious question is the means by which the grand strategy of defence research is or should be determined. In the past, ever since the end of the Second World War, there has been no effective means by which the demands of the defonce research establishments for manpower and money could be moderated by criticism from outside. It is true that there are many circumstances in which the needs of defence must be considered to be paramount, but this principle has often too easily become a means by which the defence establishments could grow without restraint and take on jobs which are not properly their business. With the reorganization of the Ministry of Defence in the past three years, it has become easier to keep the establishments properly in check. For one thing, explicit forward planning has become fashionable. More practically, central direction has become stronger. Yet there is a great deal still to be done if there is ever to be a built-in mechanism by means of which considerations which seem imperative to the Ministry of De- fence do not distort the pattern of research and development in other fields as well. The Central Advisory Council on Science and Technology is the obvious way of striking a proper balance, but it has been less than fully effective since it was set up a year ago, partly at least because the Ministry of Defence has responded with less than enthusiasm to suggestions that its research should be more fully co-ordinated with that of other agencies. To be fair, this unwillingness may also be prompted by unsureness about the future development of the Centra] Advisory Council-what kind of a body will it turn out to be ? The Select Committee on Science and Technology could help a lot by helping to define more accurately the part which the Central Advisory Council should play. It may also think it profitable to consider other schemes for coordinating defence and civil research-one possibility, for example, would be an independent research council with powers to advise on and even direct the development of defence research as if this were any other public activity.

\title{
Good Start on Natural Environment
}

THE second report of the Natural Environment Research Council is a sober document but also a worthy one. In the short period of its existence, the council has evidently taken the line that it must begin slowly and concentrate on the creation of institutions. This is sensible enough. The council owes its existence to the report of the Brundrett Committee in 1964 which argued that there was a serious need of some comprehensive organization which could sponsor and encourage the development of research in a variety of fields, from oceanography to nature conservation. In the circumstances, it is only prudent that the council should wish to be assured of a firm base for operations. The search for a better organization for the Institute of Geological Sciences typifies the problems which the council quite properly seeks to solve. Regional offices responsible for the continuing geological survey of the United Kingdom, among other things, have to be rehoused, and there is also a need to make long term decisions about the siting of the headquarters. The difficulty here is that the institute must necessarily have a double-headed role-half of its work is academic and it should properly become a catalyst of much that happens in universities, but the institute also has administrative responsibilities for geology, mining and hydrology. It is therefore sensible that the council seems convinced that any new buildings there may be should be closely linked with universities, at least geographically. Whether it will be able to satisfy its ambition to find a headquarters outside London is another matter.

If the past year has been moderately successful, however, there is not much in the new report to suggest which way the council's institutes will develop in the years ahead. It is one thing to have a decent wish to work closely with the universities and quite another to be energetic enough in the pursuit of such ideals. Indeed, for all its well-wishing on this subject, the council's latest report gives the impression that some of its establishments will remain self directing and essentially autonomous organisms with only the most arbitrary links with academic institutions, however closely interested these may be. This is why the council should ask itself whether there is not a case for duplicating some of its establishments in other environments. It would, for example, do no harm if some other university than Liverpool became so well endowed with facilities for research in oceanography that it could look the National Institute of Oceanography squarely in the face. There is also a case for asking that the dominant role of the Nature Conservancy in another field of operations should be somehow softened by the building up of well endowed centres of excellence at the universities. To say this, of course, implies no more than that competition between research establishments working in strictly academic fields is usually beneficial. And, in any case, anything which the council can do to strengthen its hold in the universities will help to strike a better balance within its budget, which at present seems to involve the spending of too great a proportion of its resources on institutions and too little on grants for supporting research projects.

\section{Russian Eclipse}

The following description of the Russian preparations for the solar eclipse of September 22, 1968, has been supplied by Evald Mustel, chairman of the Astronomy Council of the USSR Academy of Sciences, and Nataliya Yegorova, an associate of the Astronomy Council of the USSR Academy of Sciences, through the Novosti Press Agency. 